\title{
Compassionate revanchism: The blurry geography of homelessness in the USA
}

\author{
Authors: \\ Brian Hennigan, Department of Geography, Syracuse University \\ Jessie Speer, School of Geography, Syracuse University
}

\begin{abstract}
In this article, we move beyond the binary division between care and punishment in urban studies of homelessness to examine how caring institutions are themselves crucial to the punitive and exclusionary project of capitalist urbanization. Based on ethnographic and archival analysis of homelessness management in Fresno, California and Phoenix, Arizona, we show how punitive measures and institutions of care often emerge simultaneously and operate in tandem as part of a broader scheme for urban revitalization. Further, we show how caring institutions themselves often perform the function of controlling homeless people's movements in the city. Thus, we argue for a renewed focus on how capitalist urbanization produces a geography of homelessness in which the imperative to care can become compromised and complicit.
\end{abstract}

Key words: homelessness, spaces of care, public space, criminalization, urban revitalization

\section{Introduction}

In this paper, we argue that spaces of care in revitalizing cities often bolster exclusionary, antihomeless urban geographies despite their stated aim of promoting service and compassion. Based on studies of Fresno, California and Phoenix, Arizona, we show how spaces of care remained subject to the geographic pressures of urban capital, such that shelters and police departments mutually worked towards a common goal of controlling and governing homeless people's movements in the city. By historically situating the mutual development of shelters and anti-homeless policing in greater Phoenix, we highlight how compassionate models emerged alongside revanchism in responding to broader motives of revitalization. In Fresno, we show how urban revitalization pressured homeless shelters to champion the city's punitive policies, such that care workers became architects of revanchism. Together, these examples highlight how so-called spaces of care deserve greater scrutiny in revitalizing cities. They also force us to consider how such spaces function - as with anti-homeless laws - to service revitalization. 
Until recently, much of the literature on US homelessness argued that the intensifying commodification of urban space creates a punitive landscape of homeless criminalization and exclusion (Davis, 1990; Smith, 1996; Mitchell, 1997). Yet urban scholarship now overwhelmingly resists the punitive framework and characterizes homelessness management as a complex, nuanced, and often accommodating system of institutions (Parr, 2000; Conradson, 2003; Cloke, Johnsen, \& May, 2007a; Murphy, 2009; Deverteuil, May, \& Von Mahs, 2009; May $\&$ Cloke, 2013). These authors urge scholars to examine the myriad spaces of care and compassion that are made available for homeless people in the city. Building on both "camps" within urban studies, we show how spaces of care are themselves shaped by the punitive tendencies of capitalist urbanization. In this light, decontextualized analyses of compassion as individual sentiment can lose sight of how spaces of care are subject to economic pressures to remove homeless people from public space. As Smith (2009) argues, revanchism is not simply personal animus, but a structural tendency of urban revitalization to displace and exclude poor and homeless people. Further, though Deverteuil et al. (2009) acknowledge that the "abeyance" or warehousing function of shelters coincides with anti-homeless policing, the empirical dynamics of abeyance have remained largely unexamined. We intervene in this literature to show how ostensibly compassionate agencies in revitalizing cities often display a structural tendency to control and exclude unsheltered homeless people.

Critiques of the revanchism thesis not only emphasize the importance of care, but also highlight the problematic tendency of relying on studies of New York City and Los Angeles to make broad claims about the nature of urban space (DeVerteuil et al., 2009; Johnsen and Fitzpatrick, 2010). Further, such critiques contend that while US revanchist politics followed a period of disinvestment in homeless services, it is important to examine the urban dynamics of 
cities that have robust social services. In responding to these critiques, we turn our attention to two cities that have received very little attention in the literature on homelessness or urban studies, and that have experienced vastly increased service provision over the past decade. Drawing also on Stuart's (2014) emphasis on the importance of examining homelessness in marginal urban spaces, we contend that it is equally important to examine marginal cities themselves. Fresno and Phoenix offer helpful case studies in that they are understudied cities that have also been lauded as models of care and service provision. Indeed, Phoenix's homeless campus has been praised as a "national model" (Hermann, 2005) and federal officials called Fresno's homelessness management "a shining example of what's possible” (Appleton, 2015). Finally, we take up DeVerteuil's (2014) call for more complex, fine-grained ethnographies of homelessness management across locations. The analysis of Phoenix draws upon ethnographic work as a case manager in a drop-in center over 2009-2010 and ten interviews with service providers and homeless individuals in 2012. The analysis of Fresno draws on three months of ethnography conducted in 2013, as well as 24 interviews with shelter operators, public officials, activists, and homeless Fresnans. Both case studies involved exhaustive archival research of government documents and local newspaper reports up until 2013. Through interrogating abeyance in these two cities, we argue that compassionate motivations and explanations do not always produce favorable outcomes for homeless people. And this tendency emerges, we stress, because homelessness charities and police departments remain, together, pressured by the needs of urban revitalization.

\section{Care and punishment in urban studies of homelessness}


Scholars have traced a marked shift in the US urban landscape since the twilight of Fordism and dawn of neoliberalism, revealing an urgent set of policy priorities designed to attract new forms of economic investment. This process, Harvey (1989) argued, produced "entrepreneurial cities," municipalities increasingly focused on selling the landscape as "business friendly" to stoke redevelopment (Hall \& Hubbard, 1996) rather than providing public services (Logan \& Molotch, 2010; Cox \& Mair, 1988). Mayer (2012) has argued that this deepening of urban commodification has only spread — however unevenly—as cities engage in inter-urban competition for footloose capital. Endeavoring to advertise an improved, up-and-coming image, entrepreneurial cities use a range of practices to reduce the presence of marginalized groups (MacLeod, 2002).

As such, laws were drafted that targeted the activities that homeless individuals undertake to simply survive: panhandling, sitting on sidewalks, "camping" in public spaces, and pushing shopping carts (Smith 1996; Mitchell, 1997; Amster, 2008). In some cases, homeless people were "banished" altogether by trespass laws (Beckett \& Herbert, 2010), often only able to find respite in jails, shelters, drop-in centers, and welfare offices (Stuart, 2014). Hitting their stride in the 1990s, such anti-homeless laws were matched with funding for their enforcement. Aggressive arrest campaigns, property sweeps, and the bulldozing of encampments ascended, becoming normalized police practice. The criminalization of homelessness in the US has only continued to rise in the last decade, with a $43 \%$ increase in laws against sitting and lying and a 60\% increase in city-wide bans of homeless behaviors since 2009 (NLCHP, 2014). As Davis (1990) notes, anti-homeless laws are matched with anti-homeless architecture, embodied in ridged planters, gated communities, and "bum-proof” benches. Specifically designed for - or 
particularly enforced within - the centers of redevelopment, these strategies safeguard the economic growth of urban spaces of consumption (Mitchell, 1997).

Accordingly, a significant amount of homelessness research has focused on these punitive trends, illuminating how the criminalization of homelessness produces a shrunken, interstitial, isolating, and unstable geography for homeless people. Yet this punitive framing, DeVerteuil and colleagues (2009) argue, focuses too squarely upon the "collapsing" geography of homeless people. "Far from any collapse," DeVerteuil et al. (2009, p.652) explain, "there has in fact been a remarkable proliferation of homeless spaces over recent years, including the considerable expansion of abeyance, ambiguous and interstitial structures that accommodate and support homeless people." As important as studies of the punitive framing are, DeVerteuil et al. argue, homelessness research must include "complexity," looking not only at the eradication of places of homelessness but their transformation, and how the punitive turn is accompanied by the proliferation of "spaces of care." As Cloke, Johnsen, and May (2007b,p.390) argue, spaces of care emerge "in the interstices of revanchist space to provide comfort and care to the excluded, including the homeless." It is for this reason that scholars have demanded a greater attention to the myriad geographies of care and inclusion in cities, such as homeless shelters and treatment facilities, rather than only criminalization and exclusion (Conradson 2003; Johnsen, Cloke, \& May, 2005; DeVerteuil 2006; Laurenson \& Collins, 2007).

Homeless shelters and other sorts of services, then, have been and continue to be of interest, but have also been subject to varied critiques. Shelters in particular have been characterized as places of discipline, medicalization, and control (Stark, 1994; Lyon-Callo, 2000; Hoffman \& Coffey, 2008; Murphy, 2009; Gowan, 2010). Wright (1997, p.247) argues that shelter providers have also historically engaged in a hostile relationship with street people, 
perceiving them "as not wanting to follow the rules against alcohol or be in at certain hours." Some of this hostility undoubtedly derives from the broader function of welfare policy, namely its mandate to reform recipients into "self-sufficient" individuals, to push people off of welfare and out of shelters. How this process unfolds depends upon whether recipients are deemed deserving of care. For those considered unable to work (i.e. "disabled"), relief is cast as an entitlement that is deserved. For those "able-bodied," conversely, relief is contingent upon admitting individual fault (bad mindset, addiction) and consenting to a regimen of reformation through which to achieve employment and self-sufficiency. "Relief arrangements deal with disorder," Piven and Cloward (1993,p.22) argue, "not simply by giving aid to the displaced poor, but by granting it on the condition that they behave in certain ways and, most importantly, on condition that they work." Though not all spaces of care abide by such conditions, the more established, state-funded organizations, including large homeless shelters, often maintain a focus upon reforming homeless individuals through disciplinary mechanisms Such reformation vis-àvis work enforcement, moreover, is codified in broader welfare policy (Soss, Fording, \& Schram 2011).

A purely disinterested care by shelters and other homelessness services, then, is by no means a given. Indeed, the care of such institutions is inseparable from the imperative to reform, and to improve the economic position of clientele through individualized prescription and discipline. In addition to the ambivalent nature of care, caring agencies are not immune to the pressures of capitalist growth, and must often compete for funding in an increasingly corporatized non-profit sector (Cloke, Johnsen, \& May, 2007a; Buckingham, 2009). Further, as DeVerteuil (2014, p.880) argues, spaces of care perform the key function of abeyance- "where the voluntary sector acts as a container"- and operate within a broader urban landscape that 
includes punitive measures. As DeVerteuil (2014) suggests, the state "cannot implement naked punitiveness without offering up some sort of alternative salvation for those deemed more deserving." Through our case studies, we show how spaces of care not only distinguish between deserving and undeserving poor people, but how they reinforce the punitive imperatives of revitalization by actively punishing those deemed undeserving: in this case, the unsheltered homeless.

Several scholars have explored how punitive and compassionate strategies are, in practice, difficult to parse. Johnsen and Fitzpatrick (2010) argue that policing is not always driven by punitive ambitions, and that anti-homeless laws can, ultimately, be put toward compassionate ends. They term this dynamic "coercive care," wherein police "safeguard the welfare of those involved in street culture" through mechanisms of enforcement (2010, p.1705). In addition to the worrying politics of this "tough love" paternalism, where the state enforces a notion of well-being that trumps any imperative to preserve choice and freedom, Johnsen and Fitzpatrick's (2010) explanation risks overlooking the broader forces at play. The authors' focus on the hostility or sympathy of individual actors risks ignoring the economic pressures to remove homeless people to foster greater revenue in a neighborhood. Further, and despite the best intentions of the police and their charitable counterparts, homeless people, whether seen as "selfdestructive" or not, are targeted by anti-homeless laws, fines and potential jail time, that never ensure a happy, caring ending. Stuart's $(2014 ; 2016)$ ethnographic study of policing in Los Angeles's Skid Row similarly addresses the blending of care and punishment in homelessness management. Focusing on the "marginal" space of Skid Row - as opposed to the "prime" space of central business districts - Stuart (2014, p.1911) finds that police officers "act primarily as 'recovery managers' acting on behalf of rehabilitative organizations to transform homeless 
people into sober, self-governing and responsible citizens." In these marginal spaces, the police use existing anti-homeless laws to threaten homeless individuals into the caring spaces of disciplinary reformation.

In the two case studies that follow, we expand on the recognition that criminalization and compassion operate in tandem. In the Phoenix case study, we illustrate that such "coercive care" not only emerges in marginal spaces, but often encompasses central business districts and the outer suburbs. Fresno sheds light on a new sort of coercive care altogether, with homeless shelters actively lobbying for the destruction of homeless encampments. Both cases, meanwhile, highlight how this blending of paternalistic care and criminalization derive from a common base: the political-economic force of revitalizing cities.

\section{Fresno: Shelters as champions of revanchism}

The city of Fresno has long struggled against the wide-scale presence of poverty and homelessness in its downtown neighborhoods. In 2011, Fresno was the second most impoverished city in the nation and also experienced the second highest rate of homelessness (Bishaw, 2012; NAEH, 2012). The downtown area, bounded by the triangular intersection of the city's three major highways, is one of the poorest in the city. For years, homeless Fresnans took refuge in sprawling encampments concentrated in the historic "Chinatown" district in the southern corner of the downtown, alongside several homeless service facilities. In interviews and casual conversations, Fresnans often lamented that the city has no urban center for middle-class shopping, recreation, and socializing. As one councilmember said: "In downtown, unfortunately, many of the neighborhoods here are shot. ... Business is dried up because they can't get anybody to come down here anymore.” As such, Fresno officials worked for more than a decade to 
implement a massive downtown redevelopment project (Speer 2016; 2017). Yet the downtown encampments were seen to hamper nearby developments, including a \$61 million-dollar baseball stadium designed to bolster downtown growth. As such, homeless management in Fresno is intrinsically tied to the city's perceived need to revitalize urban space.

As part of its revitalization project, the city passed several laws to move homeless people out of the downtown. Fresno municipal code severely restricts panhandling and imposes prison time on violators (Fresno Municipal Code $\S 9-2608$ ). Pushing a shopping cart is also punishable by $\$ 1000$ in fines and up to one year in jail (Fresno Municipal Code $\S 9-31$ ). For more than a decade, the city has also implemented a maverick policy of bulldozing homeless encampments. Over the course of a two-year period beginning in 2005, it conducted at least 50 sweeps. Each time, homeless people built new encampments. By 2006, the city was bulldozing the same encampment in downtown Fresno every two weeks (Kincaid et al. v. Fresno, 2006). In the summer of 2013, it bulldozed every camp in the city and set up a police taskforce to prevent anyone from erecting a tent in the future. Alongside this punitive intervention, the housing authority expanded the provision of housing vouchers to the "chronically homeless" and was widely praised for its homelessness management efforts.

Anti-homeless laws and housing vouchers were both intimately tied to urban revitalization. In an interview, a homeless man indicated that the heavy presence of homelessness in the downtown area would make revitalization impossible: “They can't revitalize downtown Fresno ... I mean who wants to live like that? Party with a bunch of homeless people?" When asked what the city should do, he said there was no solution - there were no jobs and not enough shelters, and the city was just going to "lock them all up." Meanwhile, Fresno's mayor lauded the success of downtown revitalization, citing the new lofts popping up all over 
downtown (City of Fresno, 2011). A major downtown property developer explained the connection between homelessness and revitalization in Fresno:

We need to grow our economy here, so I think the net effect of homelessness here is far more severe than it is in a city that's already got other assets or attributes which draw people. In my mind, to make revitalization a success, we need to make downtown Fresno a destination. We have not been able, to this point, to identify a workable model for making that connection - make it a destination. And without dealing with the homeless problem I think it's simply makes it even more difficult.

This same developer also spearheaded Fresno's “Ten Year Plan to End Chronic Homelessness” and was instrumental in expanding housing for the homeless while also overseeing encampment evictions. Beyond private businesses, the non-profit sector was also instrumental in shaping homelessness policy. In ensuring their institutional longevity, Fresno's shelters became key players in promoting downtown evictions.

Poverello House is Fresno's primary homeless service provider, providing free meals three times a day and hosting an outdoor shelter (NCH, 2010). Jim Connell, a former stockbroker, began as CEO in the 90 s to streamline the organization as it became more institutionalized. Under Connell's supervision, Poverello encouraged a contentious relationship between shelter staff and street populations and has repeatedly targeted tent cities that develop in front of its property. In 2003, at the request of shelter officials, police officers and sanitation workers dismantled an encampment that had developed on a former junkyard adjacent to the shelter (City of Fresno, 2007). In 2011, police again removed an encampment after the shelter complained, and the shelter banned all campers from using their services (Rhodes, 2011). During court testimony in a case filed against the city seeking restitution for evictions, Connell described the destruction of homeless people's bicycles and shopping carts as "compassionate" (Rhodes, 2006), suggesting that he viewed his actions as form of "tough love." 
By 2013, the Poverello House was surrounded by three of Fresno's seven street encampments. Connell explained in a personal interview why he wanted the encampments removed:

We've seen the number of people coming for services, particularly at the women's center and the clinic, go down dramatically this year. And the anecdotal evidence is that particularly the women and children are afraid to go through that gauntlet to get in here. So it is affecting our services. ... I've had several meetings with the mayor and different people in the administration and they say they plan on cleaning it up.

Connell sought to remove the encampments to ensure that others could more easily access services, and to safeguard his organization's attendance rates for funding purposes. In this way, the impetus to care - for both the "deserving" poor and the organization itself - led to a punitive stance towards homeless campers.

Sherry Oliver ran a day shelter for women located near the Poverello House. Like Connell, she also encouraged evictions and lamented that many of her clientele, mostly the housed poor, had stopped coming since the encampments developed around the property:

You don't see nearly the families anymore that you used to because I think they just don't want to come through that maze. ... Obviously you don't want this encampment to be located here. That's hurting your services and your ability to provide them. ... It's a dilemma, because yes people need their freedom and they have a right to live, but the impact on everybody else is very difficult.

She was worried that the shelter's summer programs might be cancelled due to low attendance, and sympathized with those who did not want to walk through the encampments. Thus, she saw that the very existence of her organization was threatened by the presence of encampments. Just as private businesses often complained that homelessness prevented customers from patronizing their stores, Fresno shelters also sought to protect their attendance rates by removing encampments outside their facilities. In the process, they were forced into the paradoxical 
position of simultaneously caring for homeless people while championing their forced removal from public space.

In addition to protecting their attendance rates, shelter operators were also concerned with government approval. With Fresno's downtown being encroached by development, shelters felt the squeeze of revitalization. Faced with the ongoing threat of city opposition, shelter operators repeatedly complained that their existence was tenuous. City officials often framed downtown shelters as a magnet for the homeless and occasionally threatened to remove the shelters altogether. This magnetism exacerbated the hostile relationship between shelter operators and street campers. As a local activist recounted, he had seen "constant proposals for moving the Poverello and the Rescue Mission even further south of the downtown area." When Connell was asked if he was worried about the city's push to revitalize downtown, he said, "That's the city's attitude—-the reason we have the problem out there is because we're here. Bruce Rudd, the city manager, that's his opinion. They [the homeless] wouldn't be there if we weren't here." For Connell, the concern was not simply that his numbers were declining but also that the camps threatened the continued existence of his organization.

The Fresno Rescue Mission, a local religious shelter for men, was headed for years by Larry Arce, a former reverend and probation officer. Over the years, the Mission had been periodically threatened with city disapproval, and Arce had taken matters into his own hands by directing and funding a series of private evictions. In 2006, Mission staff, armed with a fork lift and dumpster, destroyed a nearby encampment on public property. One woman lost her tent and had nowhere to sleep that night. When activists tried to retrieve the tent from the Mission's dumpster, Arce called the police and accused them of stealing (Rhodes, 2007). In 2008, several homeless Fresnans sued the Mission, describing in their complaint how the Mission destroyed 
tents containing bedding, clothing, jewelry, family photos, birth certificates, and even heart medicine. During court testimony, Arce admitted that the shelter destroyed people's property even when they left their carts on the street to stand in line at the Mission for a meal (Rhodes, 2008). Yet Arce's actions cannot be explained only as personal animus. In an interview, he described experiencing pressure from the city:

Years ago they wanted to move us from here because they were building the Chukchansi stadium. ... But they were saying that if we're going to have this we need to get rid of all the homeless. We can't have them here. They'll be out here in the front. They'll be accosting people. They'll be begging. All kinds of perceived things were going to happen so they were blaming us - that we had to leave, we couldn't be here, we had to get out of the way.

Thus, Arce's aggressive stance against encampments was rooted in the bottom line of his organization - if the city saw that his shelter was surrounded by street encampments, it would be targeted for removal as revitalization expanded into the neighborhood.

Aside from the pressures of revitalization, notions of care themselves were often rooted in capitalist ideologies that distinguish between the "deserving" and "undeserving" poor. Like many in Fresno, Oliver perceived the homeless people living in encampments as hardened criminals. She said: "You take your life in your hands to walk down F Street right now. ... I'm not sure where some of these people came from." She told me she had been lobbying the city to remove the encampments for quite some time and said, "hopefully, things will move now that they've gotten the message that it is violent out there." Arce's actions were also deeply informed by an evangelical vision of care as religious reformation. In 2007, he had been the driving force behind a proposal to officially criminalize camping city-wide. He said:

Me and Jim Connell worked on a comprehensive project ... where the city would pass an ordinance and say you cannot camp out willy nilly anywhere you want to, in front of people's houses, in front of businesses out on the streets. ... That's not the way people live. You need to get into a program, you need to get your life together. 
Thus, Arce promoted evictions and criminalization because he rejected "the way people live" in the encampments. He was relieved when Fresno's Police Chief, who was also a Rescue Mission board member, began pushing aggressively for evictions in 2013 .

As such, encouragement of evictions is not evidence of a lack of care, but of the ambivalent nature of care and its vulnerability to the pressures of revitalization. Although shelter operators urged the city to bulldoze the encampments surrounding their shelters, they simultaneously described themselves as having compassion for the poor. Yet the nature of their organizations - as private institutions in need of continued funding and government supportdemanded punitive action. As Cloke, Johnsen, and May, (2007a) note, the individual agency of volunteers is often impinged by organizational practices and norms. When private institutions are tasked with caring for the homeless, their need to attend to their own financial security often requires punitive action. The situation in Fresno reveals how private institutions of care are also subject to the pressures and ideologies of capitalism that punish homeless people, and in their efforts to "care" for the institution itself, as well as its residents, managers furthered punitive practices against homeless people who live in public.

\section{Phoenix: Abeyance as punishment}

In 2005, Phoenix developed "The Human Services Campus," an enclosed space designed to consolidate and streamline homelessness related services. It became a cause for celebration. "Until now," William Hermann (2005), columnist for the Arizona Republic wrote, "the chronically homeless, many suffering from mental illness, have had to go to many different agencies to find help, [but] today they are all on one campus." "The $\$ 24$ million, 14-acre campus," he continued, "brings together five agencies that help the homeless, as well as 
therapists, counselors, and advisers from state, county, city, and private agencies." The creation of the Campus around CASS (Central Arizona Shelter Services), the metro region's largest shelter, solidified the impoverished neighborhoods of south Phoenix as the place to access supportive services (Brinegar, 2003). Present for the grand opening, a mental health and homelessness advisor to the Bush Administration opined that the Campus "could be a national model" (Hermann, 2005). Since 2005, the facility continually attracts 1,300 individuals each day (Arizona Republic, 2010) and, in 2012, sheltered 740 nightly (HUD, 2012) of the estimated 25,832 people experiencing homelessness throughout the year (DES, 2012). The Campus, Hermann concluded, "is more than a haven, it's a magnet."

Indeed, the executive director of CASS, Mark Hollernan, stressed the project's ingenuity in terms of its geographical pull. "We've learned you need to offer a sort of 'one-stop' shopping approach," he explained. "You provide a comfortable place to get off the streets, provide food, medical care, substance abuse treatment and mental-health counseling, housing advisers. ... Everything and everybody in one place" (quoted in Hermann, 2005). Beyond pure, disinterested care, however, later reports explicitly state what Hollernan only implies: that the Campus also functions to protect adjacent property values and keep homeless individuals from walking a mile northward to gentrifying downtown Phoenix. "Our first outcome," Hollernan explains, "is to get everybody [homeless people] there [to the shelter] to tomorrow, nothing else, because if we know they're there, that means they're not somewhere else potentially causing problems to themselves, the people around them or properties" (quoted in Lee, 2013). Here, it is clear that the Campus not only embodies a collection of relief services dedicated to caring for homeless people, as a "space of care," it also explicitly functions to remove homeless people from public 
space, away from the nearby, gentrifying downtown. In this way, its goal mirrors that of antihomeless laws and anti-homeless architecture.

The "magnetism" of the Campus, though, is not complete. Its incompleteness has much to do with the Campus's surrounding geography. The south Phoenix neighborhood that houses the Campus is, in street lexicon, referred to as "The Twilight Zone" ("The Zone" for short) in reference to its high crime rate, rampant drug use, homelessness and prostitution, factors that preceded and are now exacerbated by the Campus's presence (Amster, 2008; Brinegar, 2003). Indeed, the Zone was "the wrong side of the tracks" epitomized, a place of danger and heterotopic decay only to be ventured toward in cases of desperation (when no other areas provided needed services). "A single man trying to get into shelter," Theresa James, former Homelessness Coordinator for the nearby City of Tempe explained, "has two choices: CASS and the men's shelter in Mesa [another metro suburb], which only permits the employed. Frankly,” she continued, "I wouldn't want to go down to CASS either." Sam, a formerly homeless man, likewise expressed the dangers of the Zone: "I don't go down by the [railroad] tracks by CASS or stuff because you'll get killed. That's just the way it is." These observations reveal how the Campus is, for many, a place of last resort. It also attests to why the southeastern suburb of Tempe, a city with no permanent shelter and only a handful of services, contains more than its proportional share of homeless individuals - once estimated at around 500 (Hermann, 2008) even with a substantial arsenal of anti-homeless ordinances.

The magnetism of the Campus, then, is not strong enough to contain homeless individuals, despite its vast, superstore-esque expansion and its potential to be a national model of homeless relief services. It is within this incapacity that other modes of spatially managing homeless people come into play, particularly anti-homeless laws. Indeed, criminalization and 
compassion have always worked together throughout greater Phoenix's history of homeless management. Several years after grabbing national headlines for outlawing lying down or sleeping in public space, banning relief services in its erstwhile skid row, and then bulldozing a large homeless encampment over the 1982 Thanksgiving holiday (Sexton, 1983; Alter et al., 1984; Luckingham, 1989; Brinegar, 2003), Phoenix established CASS, the city’s first large-scale permanent shelter and predecessor to the Campus. In 2005, the same year CASS was upgraded to the Campus, the Phoenix City Council passed its current anti-camping ordinance, joining the other citywide ordinances that criminalize "aggressive panhandling" and loitering. The timing of these interventions - simultaneously increasing shelter capacity and anti-homeless policing suggests that they work jointly to spatially manage homeless populations.

Crackdowns on homeless people and their means of survival, then, remained both significantly ineffective and, in the eyes of business improvement districts and policymakers, perpetually necessary. Even after metro Phoenix became a leader in the compassionate management of homelessness with the Campus, it continually swept homeless people from parks (Poletta, 2011), evicted and bulldozed riverbed encampments (Coe, 2011), installed antihomeless architecture (Walsh, 2012), and stepped-up anti-panhandling campaigns (Smokey, 2008). Tempe, for instance, undertook a four day "sting operation" on Mill Avenue central business district in 2009, complete with undercover police officers, to crackdown on aggressive panhandling (Náñez, 2009a). Although each of these cases deployed older laws, in each instance journalists attached a compassionate framing to these punitive tactics. Upon arrest or eviction, newspaper articles explain how homeless individuals were compassionately counseled by regretful police officers about the resources offered by the Human Services Campus. During Tempe's crackdown, local police distributed cards containing both information about services 
and the specifics of the anti-panhandling law (Náñez, 2009b), such that criminalization and compassion were all on a single pocket-able card. In this sense, Tempe police acted in a "caring" capacity, offering on-the-street advice on where to receive care, at the very same time they presented the threat of imminent arrest.

Another example of the blurring between the pull of services and the push of antihomeless laws is captured by recent police actions in the Sunnyslope neighborhood of northcentral Phoenix. A poorer suburb with a disproportionate number of homeless individuals, Phoenix police have continually targeted "homeless hangouts" through monthly sweeps as residents and businesses repeatedly report "transients drifting into commercial areas after stopping at nearby homeless shelters and soup kitchens" (emphasis added) (Ferraresi, 2009b). Homeless populations in Sunnyslope are, in this example, posed as objects aimlessly moving about the community and "drifting" into foreign spaces. But their infraction is framed as both deviant and pitiful, and the actions of the police reflect this framing. "The first thing officers do on sweeps," Ferraresi (2009a) explains, "is to provide transients with information on homeless shelters and human services," while the second thing they do, the article states, "is push for maximum 180-day jail sentences for transients in violation of travel restrictions [trespassing stipulations]." One could argue that these officers first provided service referrals to skirt claims of cruelty, but it is also likely that the Phoenix Police Department comprehends the limitations of arrest campaigns to spatially manage homeless populations.

The intertwined processes of care and punishment are even more apparent around the marginal spaces of the Zone, as Stuart (2014) found in Los Angeles. "They act like cops but think like social workers," a column in The Arizona Republic begins. "About seven years ago [2005]," columnist Michelle Lee (2012) explains, "the Phoenix Police Department walking-beat 
squad that patrols the Human Services Campus in downtown Phoenix came up with a new strategy to deal with homeless people on their beat: help them connect with social services rather than arresting them for every minor misdemeanor." "There was a philosophical change," Lieutenant Sean Connolly of the Phoenix Police Department recalled. "All we would do is arrest our way to solutions. There was no sustainability in the process" (quoted in Lee, 2012). The "solutions" of Phoenix's anti-homeless laws, in other words, significantly failed to erase homelessness while likely costing the city fortunes in booking and jailing (see NLCHP, 2011). Disillusioned, in 2005 officers patrolling the Zone were given special training in crisis intervention and social work interviewing techniques to better manage the "chronically homeless" and mentally ill. Under this new strategy, immediate arrest is no longer the sole action used to clear homeless people from the street and into the Human Services Campus. Instead, officers "use the threat of arrest as leverage to keep them on track with their services, making arrests only if they have exhausted all other options," a strategy that reduces punitive costs and helps push the otherwise-intractable homeless population into the Campus or related agencies for shelter and rehabilitative services. But the mere threat of arrest does not always work to move homeless people along or toward services. Although these police officers have special training such that they can mimic the role of a social worker, Lieutenant Connolly stresses that arrests can be, and often are, made on their homeless beat. "They make it clear," Lee (2012) concludes, “'Don’t take my kindness for weakness."

Even when these officers' "kindness" is not mistaken for weakness, the Human Services Campus, along with police officers and businesses in the adjacent central business district, still find it difficult to contain homeless people in the Campus and the depressed neighborhood that hosts this institutional enclave. In 2006, in an effort to rectify this apparent shortcoming, CASS 
developed a program whereby "a team of Phoenix police and CASS specialists began crisscrossing downtown Phoenix four nights a week to engage homeless people who have severed connections with service providers" (Collom, 2009). Night "outreach" is accompanied by daybreak patrols who wake homeless individuals they find and then attempt to "persuade them to sign up for the services they need" (Lee, 2012). This melding of social work and penal strategies aims at moving homeless populations off the streets and into shelters (through threatening arrest, offering referrals in addition to arrest, or doing street outreach and transporting individuals to the Campus). Even with such punitive and compassionate tenacity, the outreach team reports that only $35 \%$ of those confronted are persuaded and enter into some sort of "treatment" (Collom, 2009), which could entail anything from entering drug rehab to continually meeting with a case manager. The pull of treatment/shelter and the push antihomeless laws remains considerably ineffective, such that push and pull factors in the geographies of homelessness often function together to drag homeless people into services, and away from public spaces.

Rather than primarily enacting "compassionate" policies throughout the 1980s "homeless crisis," as some general histories of American homelessness suggest (Gowan, 2010; Mitchell, 2011), from the beginning metropolitan Phoenix combined punitive and compassionate forms of management to constrict the geography of homeless people. Indeed, these two modes of managing homeless continually compensate for the other's failings, pushing where the shelter's pull was insufficient, pulling (and concentrating) when anti-homeless laws had aimlessly banished. Such blending of criminalization and compassion has evolved to the point where they are in fact indistinguishable, where "cops think like social workers" and social workers walk the beat. This, in turn, shows how the city's geography of care - despite being lauded as a national 
model - is crucial to the project of excluding homeless people from the city in order to create a more palatable urban landscape.

\section{Conclusion}

These two case studies reveal that binary analyses of care and punishment distract from more dialectical understandings of how revitalization impacts those excluded from the protections of private property. In practice, the city is neither a flat field of punitive processes, nor a terrain marked by the proliferation of private caring spaces. Further, although both care and punishment have different means and represent separate ideologies, the ends are often the same: to spatially manage poor and homeless populations to shore-up capital projects in revitalizing urban spaces. In both Fresno and Phoenix, homeless shelters assisted in the project of criminal enforcement. Simultaneously, anti-homeless laws were framed as compassionate mechanisms by which to push homeless people into the spaces of care they so desperately needed. Thus, compassion and criminalization must be understood recursively, as the line between social worker and police officer is intentionally muddled in Phoenix, and shelter operators in Fresno become architects of eviction.

Beyond the blurred geography of care and punishment, this paper shows how institutions of care are themselves subject to the revanchist pressures of urbanization. As our case studies reveal, institutions of care are part of a larger program of homelessness management that must negotiate the capitalist city. In Fresno and Phoenix, private caring institutions and actors often responded to revitalization by promoting punitive practices against the unsheltered homeless. In turn, unsheltered homeless people were often deemed "undeserving" of care for refusing to be sheltered. This is not to say that all caring organizations are problematic. Indeed, both Fresno and 
Phoenix are home to activist movements that promote the rights of homeless people, as well as care workers motivated by a deep commitment to empathy, equality and shared humanity. Yet rather than upholding care as universally pure or beneficial, we urge that urban studies must examine the pressures and constraints that can produce a compromised geography of care.

This is not only an abstract or theoretical intervention into the literature on urban homelessness. In analyzing shelters as ambivalent and historically situated rather than independent and idealized "spaces of care," scholars can remain sensitive to the ways in which private institutions of homelessness relief are deeply imbricated with the punitive state apparatus, and how homelessness is addressed by a wide range of institutions - shelters, jails, welfare offices, and prisons, for example - that all impose varying degrees of socio-spatial control. In the contemporary US city, the capitalist development of urban space still functions to control homeless people's movements, regardless of whether this control is motivated by compassion or revanchism. Thus, it is essential to examine on-the-ground spatial dynamics of homelessness management holistically rather than characterizing spaces of care as discrete sites that operate outside of the pressures of the capitalist city. As cities increasingly unroll new caring models of homelessness management and open new spaces of care, these policies and spaces must remain subject to critical examination and placed in the larger context of urban capitalism. With this in mind, both traditionally "caring" and "punitive" institutions must seek to overcome the institutional and ideological barriers to achieving a more radical, inclusive, and empowering city for everyone.

\section{Bibliography}

Alter J, Buckley J, Taylor M and Doherty S (1984, January 2) 
Fighting Back: Arizona and Massachusetts represent the extremes. Newsweek, 26.

Amster R (2008) Lost in Space: The Criminalization, Globalization, and Urban

Ecology of Homelessness. New York, NY: LFB Scholarly Publishing.

Appleton R (2016, November 28) Feds call Fresno, Madera 'a shining example' in

homelessness battle; local agencies say it's not that simple. The Fresno Bee.

The Arizona Republic (2010, November 10) Opinion: In 5 years, campus established hope. The Arizona Republic.

Bakker I (2003) Neo-liberal governance and the reprivatization of social reproduction: Social provisioning and shifting gender orders. In Isabella Bakker, and Stephen Gill (Eds.) Power, production, and social reproduction: Human in/security in the global political economy (pp. 66-82). Basingstoke, UK: Palgrave Macmillan.

Beckett K and Herbert SK (2010) Banished: The New Social Control in Urban America. New York, NY: Oxford University Press.

Bishaw A (2012, September) Poverty: 2010 and 2011. American Community Survey Briefs, United States Census Bureau.

Brinegar SJ (2003) The social construction of homeless shelters in the Phoenix area. Urban Geography 24(1): 61-74.

Buckingham H (2009) Competition and contracts in the voluntary sector: exploring the implications for homelessness service providers in Southampton. Policy \& Politics 37(2): 235-254.

City of Fresno (2007, October 2). Report to the City Council re: Appropriation for Poverello House/Village of Hope.

City of Fresno. (2011, June 1). Mayor Swearengin delivers State of the City Address 
[Press Release].

Cloke P, Johnsen S and May (2007a) Ethical citizenship? Volunteers and the ethics of providing services for homeless people. Geoforum 38(6): 1089-1101.

Cloke P, Johnsen S and May J (2007b) The periphery of care: Emergency services for homeless people in rural areas. Journal of Rural Studies 23(4): 387-401.

Coe J (2011, May 12) Avondale cleans up transient camps in Agua Fria riverbed. The Arizona Republic.

Conradson, D (2003) Geographies of care: spaces, practices, experiences. Social \& Cultural Geography 4(4): 451-454.

Cox K and Mair A (1988) Locality and community in the politics of local economic development. Annals of the Association of American Geographers 78(2): 307325.

Davis M (1990) City of Quartz: Excavating the Future of Los Angeles. New York, NY: Verso.

Dear M and Wolch J (1987) Landscapes of Despair: From Deinstitutionalization to Homelessness. Princeton, NJ: Princeton University Press.

DES. (2012). Homelessness in Arizona annual report. Phoenix, AZ: Arizona Department of Economic Security.

DeVerteuil G (2006) The local state and homeless shelters: Beyond revanchism? Cities 23(2): 109-120.

DeVerteuil G (2014) Does the punitive need the supportive? A sympathetic critique of current grammars of urban injustice. Antipode 46(4): 874-893.

DeVerteuil G, May J and von Mahs J (2009) Complexity not collapse: 
Recasting the geographies of homelessness in a punitive age. Progress in Human Geography 33(5): 646-666.

Ferraresi M (2009a, February 26) Police sweep targets transients trespassing in neighborhood. The Arizona Republic.

Ferraresi M (2009b, March 4) Resident complaints spur homeless-hangout crackdown. The Arizona Republic.

Fresno Municipal Code, Chapter $9 \S 2608$ (2014).

Fresno Municipal Code, Chapter $9 \S 31$ (2014).

Gowan T (2010) Hobos, hustlers, and backsliders: Homeless in San Francisco. Minneapolis, MN: University of Minnesota Press.

Hall T and Hubbard P (1996) The entrepreneurial city: New urban politics, new urban geographies? Progress in Human Geography 20(2): 153-174.

Hermann W (2005, February 11) “One-stop shop” for city’s homeless. The Arizona Republic.

Hermann W (2008, December 18) Tempe churches offer shelter to homeless. The Arizona Republic.

Hoffman L and Coffey B (2008) Dignity and indignation: How people experiencing homelessness view services and providers. The Social Science Journal 45(2): 207-222.

HUD. (2012). HUD's Continuum of Care Homeless Assistance Programs Inventory Count Report. Department of Housing and Urban Development. Johnsen S and Fitzpatrick S (2010) Revanchist Sanitisation or Coercive Care? 
The Use of Enforcement to Combat Begging, Street Drinking and Rough Sleeping in England. Urban Studies 47(8): 1703-1723.

Johnsen S, Paul C, and May J (2005) Day centres for homeless people:

Spaces of care or fear? Social \& Cultural Geography 6(6): 787-811.

Kincaid et al. v. City of Fresno (2006) Statement of decision and findings re: Plaintiffs' application for a preliminary injunction.

Laurenson P and Collins D (2007) Beyond punitive regulation? New

Zealand local governments' responses to homelessness. Antipode 39(4): 649-667.

Lee MY (2012, April 13) Phoenix police aid homeless with new strategy. The Arizona Republic.

Lee MY (2013, July 16) Crush of homeless overwhelming Phoenix shelter. The Arizona Republic.

Logan J and Molotch H (2010) The city as a growth machine. In Japonica Brown-Saracino (Ed.) The Gentrification Debates: A Reader (pp. 87-102). New York, NY: Routledge.

Luckingham B (1989). Phoenix: The History of a Southwestern Metropolis. Tucson, AZ: University of Arizona Press.

Lyon-Callo V (2000) Medicalizing homelessness: The production of self-blame and self-governing within homeless shelters. Medical Anthropology Quarterly 14(3): 328-345.

MacLeod G (2002) From urban entrepreneurialism to a "revanchist city"? On the spatial injustices of Glasgow's renaissance. Antipode 34(3): 602-624.

May J and Cloke P (2013) Modes of attentiveness: Reading for difference in 
geographies of homelessness. Antipode 46(4): 894-920.

Mayer M (2012) The "Right to the City" in Urban Social Movements. In Neil

Brenner, Peter Marcuse, and Margit Mayer (Eds.) Cities for People and Not for Profit:

Critical Urban Theory and the Right to the City (pp. 63-85). New York, NY: Routledge.

Mitchell D (1997) The annihilation of space by law: The roots and implications of anti-homeless laws in the United States. Antipode 29(3): 303-335.

Mitchell D (2011) Homelessness, American style. Urban Geography 32(7): $933-$ 956.

Murphy S (2009) “Compassionate” strategies of managing homelessness: Postrevanchist geographies in San Francisco. Antipode 41(2): 305-325.

National Alliance to End Homelessness. (2012). State of homelessness in America.

National Coalition for the Homeless. (2010). Tent cities in America: A Pacific Coast report.

National Law Center on Homelessness and Poverty. (2011). Criminalizing crisis: The criminalization of homelessness in U.S. cities.

National Law Center on Homelessness and Poverty. (2014). No safe place: The criminalization of homelessness in US cities.

Náñez D (2009a, July 2) Advocates for homeless critical oh Tempe crackdown. The Arizona Republic.

Náñez D (2009b, July 17) Effects of panhandling crackdown still being felt. The Arizona Republic.

Parr H (2000) Interpreting the hidden social geographies of mental health: 
Ethnographies of inclusion and exclusion in semi-institutional places. Health and Place 6(3): $225-237$.

Poletta M (2011, November 15) Phoenix police, other city employees help homeless at Hance Park. The Arizona Republic.

Rhodes M (2006, November 8) Homeless stand up for their rights in court. The Community Alliance Newspaper.

Rhodes M (2007, April 20) With friends like these ... The Community Alliance Newspaper.

Rhodes M (2008, July 1) Lawsuit filed against the Rescue Mission. The Community Alliance Newspaper.

Rhodes M (2011, February 2) Fresno homeless czar harasses the homeless. The Community Alliance Newspaper.

Sexton PC (1983) The life of the homeless. Dissent 30(1): 79-84.

Smith N (1996) The New Urban Frontier: Gentrification and the Revanchist City. New York, NY: Routledge.

Smokey SJ (2008, June 5) Resident working for safer area. The Arizona Republic.

Soss J, Fording R and Schram S (2011) Disciplining the Poor: Neoliberal Paternalism and the Persistent Power of Race. Chicago: University of Chicago Press.

Speer J (2016) The right to infrastructure: A struggle for sanitation in Fresno, California homeless encampments. Urban Geography 37(7): 1049-1069. 
Speer J (2017) "It's not like your home": Homeless encampments, housing projects, and the struggle over domestic space. Antipode 49(2): 517-535.

Stark L (1994) The shelter as 'total institution.' The American Behavioral Scientist 37(4): 553-553.

Stuart F (2014) From 'rabble management' to 'recovery management': Policing homelessness in marginal urban space. Urban Studies 51(9): 1909-1925.

Stuart F (2016) Down, Out, and Under Arrest: Policing and Everyday Life in Skid Row. Chicago, IL: University of Chicago Press.

Walsh J (2012, November 8) Renewed Mesa park sign of hope. The Arizona Republic.

Wright T (1997) Out of Place: Homeless Mobilizations, Subcities, and Contested Landscapes. Albany, NY: SUNY Press. 